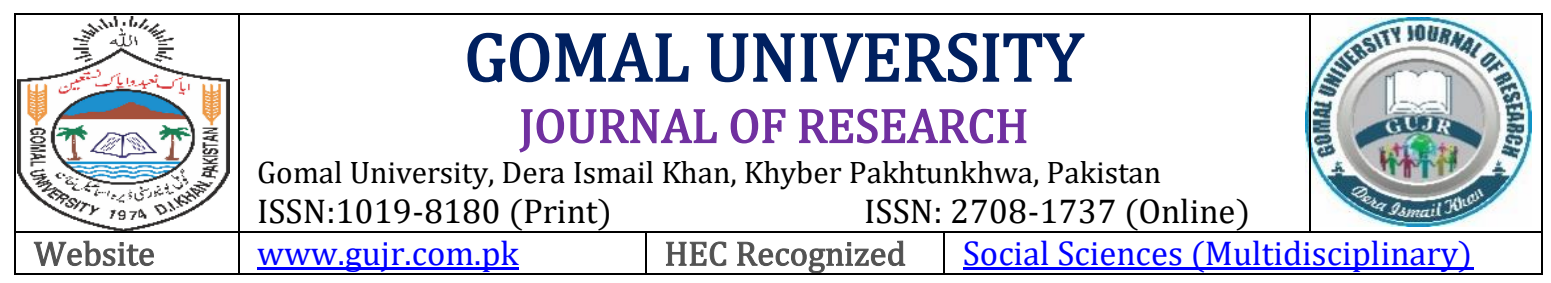

\title{
EMERGENCE OF FINANCIAL TECHNOLOGY IN ISLAMIC BANKING INDUSTRY AND ITS INFLUENCE ON BANK PERFORMANCE IN COVID-19 SCENARIO: A CASE OF DEVELOPING ECONOMY
}

\author{
Ashfaq Ahmad ${ }^{1}$, Aamir Sohail ${ }^{2}$ \& Abid Hussain ${ }^{3}$ \\ ${ }^{1}$ Associate Professor, Hailey College of Commerce, University of the Punjab, Lahore, Pakistan \\ ${ }^{2}$ Department of Management and Administrative Sciences, University of Sargodha (Bhakkar) \\ ${ }^{3}$ Director, High Aims School Systems, Jahan Khan Bhakkar, Pakistan
}

\begin{tabular}{l}
\hline ARTICLE INFO \\
\hline Keywords: \\
Financial Technology, \\
Islamic Banks, Artificial \\
Intelligence, Mobile \\
Banking
\end{tabular}

Article History:

Date of Submission:

28-09-2020

Date of Acceptance:

20-03-2021

Date of Publication:

31-03-2021

\section{ABSTRACT}

Technological intervention and financial innovation are an essential element for the banking sector especially in post-Covid 19 scenario. Islamic banking industry has also no exception and Islamic banks could attain institutional objectives over financial technology. The motivation behind research is to investigate emergence of financial technology in Islamic Banking Industry and its Influence on Bank Performance. The population of the study consists of Islamic banks and windows of Islamic banks operating in Pakistan. The sample size consists of four Islamic banks, five Islamic windows of conventional banks, and State bank of Pakistan. Purposive sampling technique was used by researcher. Semi-structured interviews were conducted and NVIVO software was used for data analysis. Findings indicate that technologies used by different banks to serve the customer are blockchain, mobile banking, customer relations management, cyber security, cloud banking, and fintech start-up. Reaction and response of the Islamic finance industry to the rise of financial technology and its impact on Pakistan is obvious.

\begin{tabular}{l|l} 
& (c) () \$) \\
\hline Corresponding Author & Aamir Sohail: aamir.sohail@uos.edu.pk \\
\hline DOI & https://doi.org/10.51380/gujr-37-01-09 \\
\hline
\end{tabular}

\section{INTRODUCTION}

The Islamic financial industry is still rising worldwide, drawing the potential bankers both from Muslim and non-Muslim markets. Financial technology (FinTech) should play an important role in Islamic finance growth (Reuters, 2018). Technology and automation have become important parts of the global financial services market (Dubai Islamic Economy Development Centre, 2018). Fin-Tech has radically changed the way consumers performing their financial transactions (Huei, Cheng, Seong, Khin \& Bin, 2018). It is evidenced by increased investment in Fin-Tech companies around world, which reached $\$ 4,256,202$ million in 2018. Global transaction value is projected to reach $\$ 7,971,957$ million by 2022 with annual growth 17\% (KPMG, 2019). Marszk and Lechman

Gomal University Journal of Research, Volume 37, Issue 1, MARCH, 2021 
(2018) concluded that the information and communication affect economic and social conditions today matter of urgency. Fintech plays important role as medium to support everyday operations of society and world, so a new age of financial services for banks is born as Fintech is emerging (Milian, Spinola, \& Carvalho, 2019). The increasing use of the technology in financial services has a number of factors, such as increasing Banks' effectiveness by reducing cost of opportunity and encouraging greater customer loyalty so customers can enjoy financial services at any time, where and as long as they live (Aisyah, 2018). Fintech is a relatively new industry and will become even more novel when combined with Islamic finance. Recent fintech research (Biancon, Cesinaro, and Kamal, 2019; Lacase, Lambert \& Khan, 2017; Lalin and Furqani, 2019) did not comprehensively cover this topic and there is lack of the research available especially in the context of organization policies, resources, infrastructure, and the government support which are thus critical in order to implement fin-tech in letters and spirit in Islamic banking sector of an emerging economy like, Pakistan.

Earlier studies mainly integrated one of Fintech's components like crowdfunding and blockchain, that is justified as Fin-tech and its adoption in Islamic banking is early. Consequently, a number of research gaps exist in this field. Islamic financial technology, be it Islamic or non-Islamic, has received attention of many countries during COVID-19 pandemic. Islamic fintech, among other items, helps to spread technology opportunities and ensure market inclusion and much-needed instability (Tranglo, 2020). Researchers explored potential of emergence of financial technology in Islamic banking industry and its influence on performance of selected Islamic banks working in Pakistan by approaching relevant segments. Pakistan, the sixth most populous country in world, is a money-based economy, with $85 \%$ of its population economically excluded. Pakistan could become attractive market for developing fintech technologies due to increasing number of young people, a catastrophic penetration of the Internet and smartphones, consumer choices for mobile and social media, and the spread of online commerce that promotes digital payments, and overall financial system having absorption capacity for innovation. This study investigates various aspects of Fin-tech and potential impact on Islamic banking and financial sector in Pakistan. According to the best of researcher's knowledge, this research study is the first-ever attempt to discuss different concepts of fin-tech related to the Islamic banking industry in Pakistan. Moreover, it is evident that due to COVID-19 every organization face difficulty to manage their operation smoothly. This study sheds light upon the importance of fin-tech in this pandemic and specifically its implication on Islamic banking which is growing sector worldwide. The work, thus, attempts to add literature in field of Islamic Fintech by addressing core areas of Fin-tech by using the qualitative research method.

\section{LITERATURE REVIEW}

\section{Constraint-induced Innovation Theory}

Constraint-induced innovation theory by (Silber, 1983) indicating that the financial institution's objective is to maximize benefit by the financial innovation. Financial institutions are, however, subjected to internal and external (governmental) constraints for maximizing benefit through the reduction of efficiency, which also do not guarantee stability of management. Theory of restricted innovation addresses microeconomic financial innovation, emphasizing the excess innovation in adverse circumstances. Therefore, financial innovation in modes of the moderate finance cannot articulate this phenomenon entirely. This is vital whereby use of the Internet-linked information technology (IT) decreases transaction costs and allows data to be used, the management efficiency and teamwork. It provides the company's internal database with additional associated details from outside site. Thus, reduction in process costs by online banking, mobile banking and bank agencies could convince bank to achieve progress in profitability. Thus, decreasing web banking, 
mobile banking and agency banking process costs may convince the bank to make progress on its profitability.

\section{Empirical Studies on Fin-tech and Islamic Finance Industry}

There is a long history of the relationship between finance and technology. Arner, Barberis, and Buckley (2015) list the financial technology stages over years. FinTech 1.0 (1866-1967) marked the beginning of financial and technology ties, but technology was not so mature and very costly at the time, and the association therefore was not the clear. The firm groundwork for this sacred association is set by FinTech 2.0 (1967-2008). Financial institutions now realize that technology is essential for delivering higher quality customer service. FinTech 3.0 (2008) began operations with emerging technology firms and startups. Fernández (2017) argues that the financial crisis of 2008-09 has contributed to growth and rapid adoption of financial technology. A transition from core banking to non-core financial companies has been visible during this period. Analysts found that financial technology offers a wide variety of services at lowest prices directly to consumers. Financial technology has advanced greatly in recent years, leading to a rise in topics covered in recent academic articles. The substantive concept of Internet finances (Ping \& Chuanwei, 2013), Internet of financial services and company start-up innovation are for example described as the disruptive (Mehmood, Nisar \& Rehman, 2015), but this is the disruptive (Lee \& Shin, 2018) and algorithmic trading. The effect of IT on the banking industry can be seen worldwide (Butt \& Khan, 2019).

The findings of Mehmood, Nisar and Rehman (2015) have shown that the effects of IT on banking sectors are positive and substantial. Fintech has proven to be an advantageous breakthrough for the financial services sector and has increased the level of financial inclusion by reaching a diverse client base. The conditions for implementing Shari'ah are different from the conventional Fintech framework. It is important to emphasize the launch of Fintech solution provided Islamic financial institutions (IFIs) with the more resources to develop their product portfolio and infrastructure (Jamil \& Seman, 2019). Research on Fintech's application in Islamic finance has thus evolved in last few years (Hasan, Hassan \& Aliyu, 2019; Jamil \& Seman, 2019). In view of the significant increase in the number of start-ups offering products which comply with Islamic Sharia. Arvian Firmansyah and Anwar (2019) explained potential of Islamic financial systems. Examples of these firms include Robo-advice for exchange-traded fund of Wahed, Islamic alternative asset market place of Yielders, eWakalah for crowdfunding real estate of Ethics Crowd and many companies including P2P lending (Wintermeyer, Lawrence, \& Basit., 2017). Also, Arvian Firmansyah and Anwar (2019) address the prospects and challenges of Islamic financial technology. They said in interviews with experts that future of Islamic financial technology is capable, especially in Muslim countries.

Their findings are consistent with the global report on Islamic financial technology published by DinarStandard (2018), which states that the most populous regions are Muslim countries, where the millennial population exceeds highest level of smartphone penetration. The two components of millennials and smartphones are the main driving forces of the fintech market (DinarStandard, 2018). By studying the Fintech contribution and customer retention crowdfunding among Islamic banks in Malaysia and United Arab Emirates, Baber (2020) has made a substantial contribution. The results show that services focused on Fintech do not help Islamic banks to improve retention of clients. Crowdfunding services, however, have a positive impact for Islamic banks operating in Malaysia and UAE on customer retention. These findings contradict the findings of Aisyah (2018) who report that Islamic Fintech can improve financial dealings, service offerings and convenience leading to higher customer loyalty for Indonesian banks. In another study, it is concluded that Shari'ah-compliant crowdfunding invests in halal products, shares the risk of the investment, and 
does to charge interest. Fintech also allows IFIs to become more transparent by creating a direct link between the customer and investors from very beginning of the project (Biancone \& Radwan, 2019).

\section{METHODOLOGY}

This research is focused on qualitative research design. Qualitative research approach includes interviews and texture or content analysis that allow the researchers to use these instruments in achieving their research goals. Qualitative data refers to words rather than the numbers (Bryman, 2008), and is often used in situations where fewer people need a deeper and clear understanding of a particular topic. The population of the study consists of Islamic banks and windows of Islamic banks operating in Pakistan. The sample size consists of four Islamic banks, five Islamic windows of conventional banks, and State bank of Pakistan. The investigator used the purposeful sampling method. Managers are the majority of chosen individuals from the banks. They maintain contact with their respective banks' innovation, technologies and R\&D departments. This results in their views on any subjects or problems being true and accurate. The interviews were semi-structuring. The interview guide is divided into two sections. The first section covers some demographic issues such as respondent's experience, age and association and the second section cover nine issues relating to development of financial technology in the Islamic Banking Industry and their effect on banks' results. The interview took between 15 and 25 minutes. The sound was recorded and additional notes were provided by the researchers. Finally, investigators demanded respondents to share the results and to give them an electronic copy of the transcript for verification. The data analysis software Nvivo was used for data analysis. The data have been summarized and analysed at various levels, such as the data organization, identification, coding, and therefore the thematic development.

\section{RESULTS OF STUDY}

\section{Respondents' Profile}

Table 4.1 lists several characteristics of the respondents. The average age of the interviewees was 38 , and all interviewees held managerial positions. Four respondents were from full-fledged Islamic banks, five were from Conventional Islamic banks and one respondent are from the State bank of Pakistan. All managers are mature enough to understand the concept of financial technology and its impact on Islamic banks.

Table 1

Respondents' Profile

\begin{tabular}{cccclll}
\hline Row ID & Respondent ID Experience & Age & \multicolumn{2}{l}{ Nature of Bank } & Bank Name & \multicolumn{1}{c}{ Designation } \\
\hline 1 & S01 & 15 & 45 & Islamic & Al-Baraka & Manager \\
2 & S02 & 08 & 43 & Islamic & Meezan & Vice. President \\
3 & S03 & 05 & 28 & Islamic & Bank Islami & IT-Manager \\
4 & S04 & 10 & 42 & Islamic & Dubai Islamic & Manager \\
5 & S05 & 07 & 38 & C-Islamic & SBP & Director \\
6 & S06 & 08 & 36 & C-Islamic & MCB & Team Leader \\
7 & S07 & 04 & 37 & C-Islamic & Faysal bank & Manager \\
8 & S08 & 15 & 35 & C-Islamic & HBL & Manager \\
9 & S09 & 09 & 39 & C-Islamic & Al-Falah & Manager \\
\hline 10 & SO10 & 06 & 41 & C-Islamic & Allied Bank & Manager \\
\hline
\end{tabular}




\section{Thematic Analysis}

Table 4.2 shows the topics or nodes that have been coded in an informative manner for using the text. The themes are patterns of data sets essential for a phenomenon classification and related to a particular question of research (Fereday \& Muir, 2006). According to table, majority $(\mathrm{N}=69)$ of the respondents are concerned with Fin-tech in Islamic Banks. There are 43 references and all respondents spoke on digitalization and branchless banking about Fintech. Third number include 41 references from 8 respondents covers assistance, policies and industry and customers' profile. Main topics are bold and have several sub-themes. Each theme defines sources and references for each node.

\section{Table 2}

Themes, Sources, and References

\begin{tabular}{lcc}
\hline Name & Sources & References \\
\hline Understanding about Financial Technology & 10 & 69 \\
Digital Channels & 6 & 10 \\
Internet Banking & 1 & 09 \\
Mobile banking & 1 & 8 \\
ADC channels & 1 & 3 \\
Artificial intelligence & 1 & 4 \\
Online portfolio management & 2 & 4 \\
Online account opening & 1 & 6 \\
Quality service & 2 & 3 \\
Technological changes & 2 & 6 \\
Cardless ATMs & 3 & 5 \\
Cost cutting edge & 1 & 5 \\
Cloud computing & 1 & 2 \\
Digital Currencies & 2 & 4 \\
Potential Disruption Areas of the IBs & 08 & 40 \\
Future of banking & 4 & 8 \\
Public Acceptability & 1 & 4 \\
Big Revolution & 2 & 5 \\
Islamic Mutual Funds & 2 & 4 \\
Islamic Sukuk & 1 & 6 \\
Islamic Robo Advisory & 2 & 5 \\
Islamic Credit Cards & 2 & 5 \\
Market Capturing & 1 & 3 \\
Issues of Fintech & 10 & 39 \\
Infrastructure & 2 & 4 \\
Product Evaluation & 4 & 5 \\
Products related fatwas & 1 & 1 \\
Shariah compliance & 4 & 6 \\
Strict SOP's & 1 & 1 \\
Unawareness of Islamic laws & 2 & 2 \\
Resources & 2 & 3 \\
Process of financing & 2 & 4 \\
Financial habits & 2 & 4 \\
Contract terms & 4 & 2 \\
Professional Staff & & 2 \\
& 2 & 2 \\
\hline
\end{tabular}


Govt Support

Alternative Products

Fintech and Religiosity

$\begin{array}{ll}1 & 3 \\ 2 & 3\end{array}$

Shariah boards

Standards of Shariah

09

40

Product Approval

Shariah compliance

Customer journey

Customer satisfaction

Service quality maintenance

Social media channels

Web portal

Tech-Based Products

Existing Human Capital and resources

48

14

25

24

$1 \quad 6$

25

$2 \quad 2$

$1 \quad 1$

13

12

Bank resource allocation

931

Professional Bankers

13

Innovation

internal audit

$5 \quad 2$

Motivational lectures

$1 \quad 1$

3

$2 \quad 5$

Scarce Resources

$5 \quad 3$

IBs in Development Phase

Table 3

Themes, Sources, and References

\begin{tabular}{lcc}
\hline IBs in Emerging \& Traditional Economies & 07 & 36 \\
\hline Backward banking & 2 & 3 \\
Infrastructure & 1 & 2 \\
lack of awareness & 2 & 3 \\
lake of resources & 2 & 4 \\
Minimal Market share & 3 & 5 \\
The religious point of view & 1 & 2 \\
internet facility & 5 & 5 \\
Mobile payment & 2 & 2 \\
FinTech adoption & 1 & 1 \\
Promotions & 2 & 2 \\
Time taking task & 1 & 2 \\
Opportunity & 2 & 3 \\
Potential of IBs & 1 & 2 \\
Fintech and COVID-19 & 09 & 40 \\
Nonstop Banking & 4 & 8 \\
Online channels & 1 & 4 \\
Online funds transfer & 2 & 5 \\
Phone calls interaction & 2 & 4 \\
Contactless micro-finance & 1 & 6 \\
Customer policies & 2 & 5 \\
Digital products & 2 & 2 \\
Machine learning & 1 & 1
\end{tabular}




\begin{tabular}{lcc} 
Artificial intelligence & 1 & 3 \\
Big-data analytics & 1 & 2 \\
Fin-tech and Financial Inclusion & 07 & 28 \\
$\quad$ Financial literacy & 1 & 3 \\
Individual businesses & 5 & 2 \\
Trade and credit facility & 1 & 1 \\
Business activities & 3 & 3 \\
Collection payments & 2 & 5 \\
$\quad$ Corporate sector efficiency & 5 & 3 \\
Account's maintenance & 2 & 3 \\
$\quad$ RTGS & 3 & 3 \\
\hline E-biz & 2 & 5 \\
\hline
\end{tabular}

\section{Cluster Analysis}

Figures 4.1 and 4.2 reflect themes of similarities in form of hierarchies and relationships. These figures show that the potential impact of Fin-tech is divided into several topics and that similar topics are grouped. Technologies like Blockchain, smart contracts, artificial intelligence, Robo advisors and cloud computing have great potential in Islamic industry. Figure 2 shows Circle Graph, all elements are displayed as points on circumference. The similarity between the drawn ones is indicated by linking lines of diverse colors and thicknesses. Blue lines indicate parallels in contents. The results indicate customer policy, sharia compliance, Fin-tech and religiosity, financial literacy, infrastructure, human resources, and govt. support is main theme discussed by respondents.

\section{Tree Analysis}

\section{Figure 1}

Nodes compared by Number of Items Coded

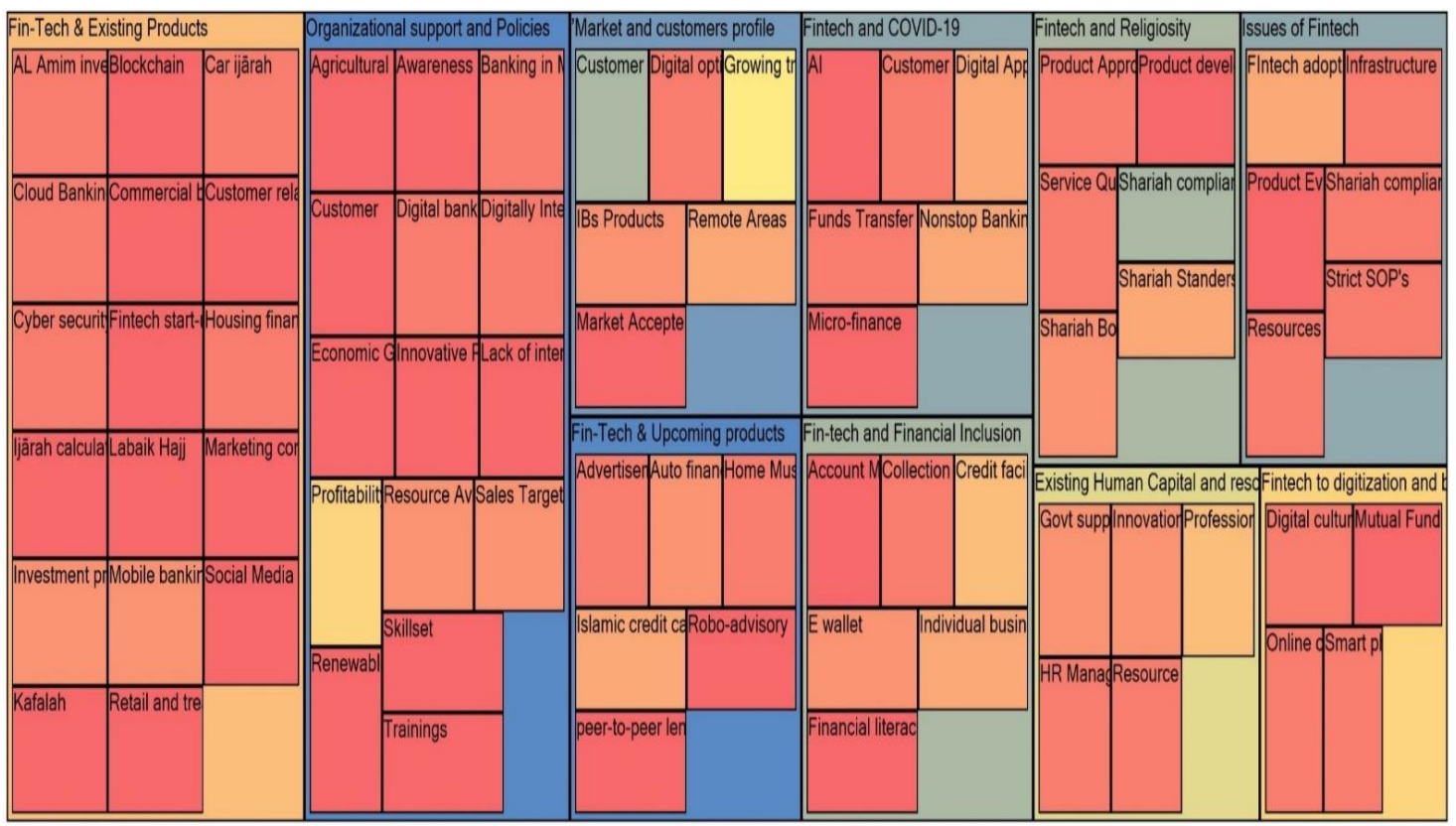


Figure 2

Circle Graph of Themes Clustered by words Similarity

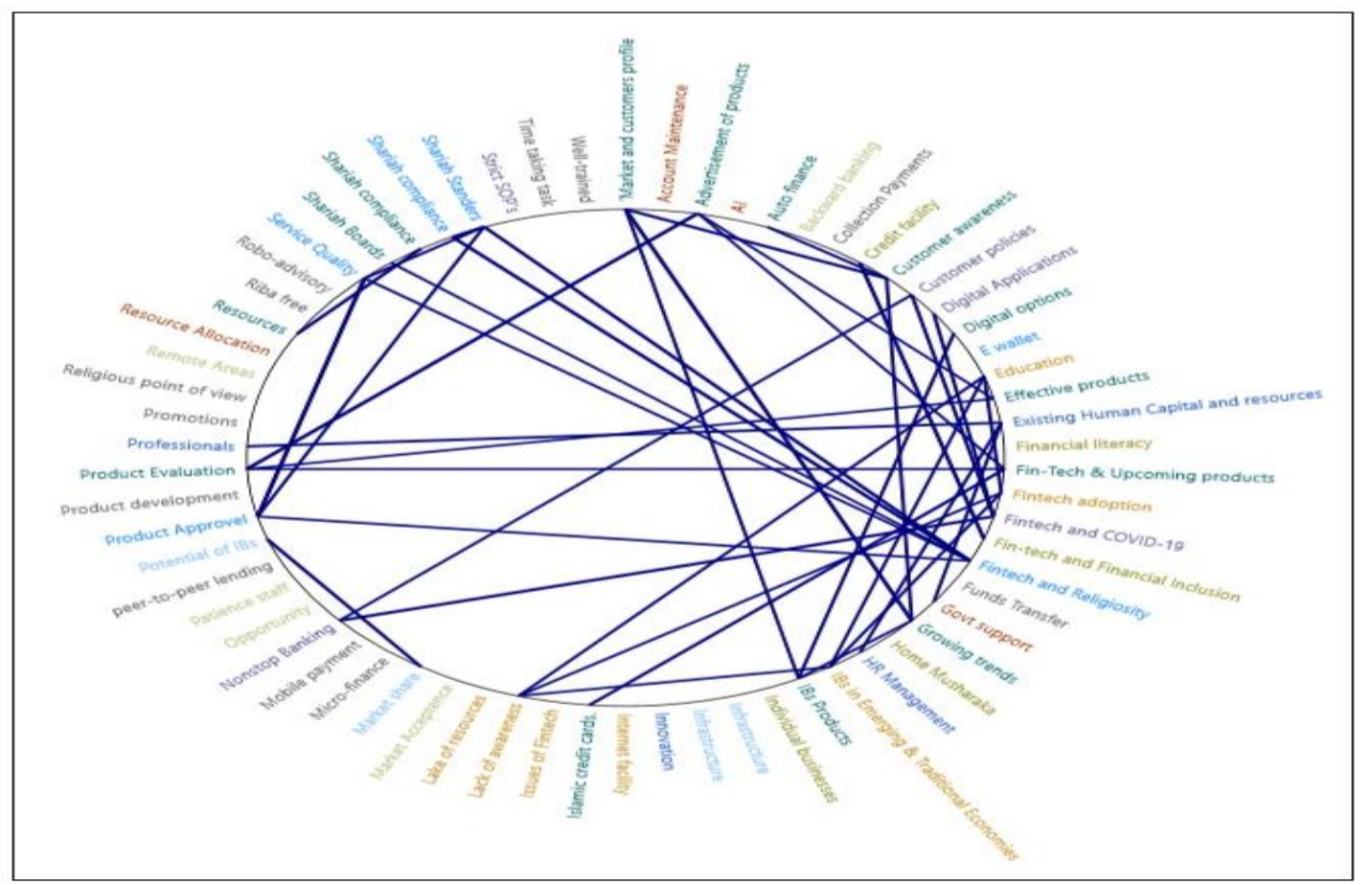

\section{DISCUSSION}

\section{Understanding about Financial Technology}

This construct discusses understanding of financial technology. Literature suggested that Fintech refers to "innovative financial services/products delivered via technology and with advancements in technology (mobile and internet) coupled with their global widespread adoption, consumers' expectations are changing" (Chuen \& Teo, 2015). Respondents share understanding of Fin-tech in following words: "Financial Technology comprises of latest technological changes brought in the market for the rapid growth of financial resources and institution like internet or mobile banking, online payments gateway for collection and payments of companies like paypro, biometric and queue matric installation in banks, online account opening in Assets Management Companies like al Meezan investment and brokerage houses like AKD Securities, etc." (R2). "Financial technology means using digital channels to facilitate customers by providing services quickly and reliably. Bank-Islami providing different services by using financial technology in which most important is Cardless ATMs with motto of "Your Thumb is Your Bank". (R3). "Over fin-tech, product access through mobile apps and online portals for self-assessment like car ijārah, housing financing” (R7).

Some of respondent stress that Artificial intelligence, Cloud computing, and Robo advisory, are under scoop of Fin-tech. Following lines confirm their statements: "Financial technology means using financial technology (mobile banking, digital apps, artificial intelligence, digital currencies, investment advice and biometric) to improves the quality of banking experience among clients" (R5). "Well! I think financial technology is a very common term in the age of digital banking for 
everyone. For me, financial technology is facilitating my financial needs by just clicking once on my mobile phone. As a practitioner, we are offering multiple channels to facilitate our customers in which investment portfolio management by giving online platforms" (R10). From responses, it is concluded that Fin-tech is a digital tool to provide financial services by Islamic Banks in a more effective way.

\section{Potential Disruption Areas of the Islamic Banking and Finance Industry}

This construct discusses the potential disruption areas of Islamic banking and finance industry specifically in context of Fin-tech. Through the different respondents' views, it shows that Islamic banking is in a developing phase in Pakistan. There are many gray areas of Islamic banking and it responds to Fin-Tech and innovation very quickly. Following responses confirm above statement: "Islamic Finance industry is responding very well in adopting FINTECH, presently we have $17 \%$ share of Islamic banking in Pakistan banking sector and amazingly Islamic banks are performing very well in all aspects specifically FINTECH, that is why their share is gradually increasing and a few of them like Meezan achieved the best banking awards as well" (R2). "Islamic banking is evolving and is considered as the future of banking in Pakistan and banks are focusing on Fintech nowadays" (R4). "Investment opportunities providing by different Islamic institutions in form of mutual funds, Sukuk, etc. greatly capture investor's attraction" (R6). One of the respondents from state bank responds that customer's awareness and desire for profitability may impact investor's decision of Islamic Banks. Moreover, customers' acceptance of Fin-tech is important. Following lines confirm above statement. "The general public acceptability of Islamic banking in Pakistan is very impressive as people want to use Islamic banking services but as far as actual customers are concerned there are some limitations just like low-profit rate and risk of loss may discourage customers to invest in Islamic banking. SBP encourages conventional banks to convert lending into Islamic landings". Above responses from different respondents clearly show that there are potential areas of Islamic banks in Islamic Sukuk, Islamic mutual funds, and Islamic lending are included.

\section{Issues of Fintech in Islamic banking}

This construct presents the views of Bankers regarding different issues faced by Islamic banks to successfully implement concept of Fin-Tech. Literature suggested that Islamic banking is facing issues like the customer awareness, resources, infrastructure, and regulation which may limit the execution of fintech in Islamic banking (Rizvi, Naqvi, \& Tanveer, 2018). Different respondents highlight a different issue in following lines: "Islamic banking as a whole face problem regarding infrastructure specifically, like people find it easy to visit please for used cars and find bank AlFalah logo right there for getting financing there but in Islamic banking, you have to evaluate products and transaction about Shariah compliance like subject matter, process of financing, contract terms, etc. So basically, there are more infrastructure problems than resources and most importantly unawareness of Islamic laws of contracts and trade" (R2). "The major issue is lake of Islamic branches in remote areas and less developing areas" ( $\mathrm{R} 7)$. "Routes of conventional banks are very deep as compare to Islamic banking so, it may face challenges like competitive products, low profit, chances of loos and Govt. Support" (R8). "Major issue of fin-tech in Islamic banking is customer awareness. The customers of remote areas feel reluctant to use digital apps like mobile banking due to lack of knowledge and when it comes to Islamic banks, it's even more difficult to understand products." (R9). In conclusion, like commercial banking, Islamic banking is not as strong as follow strict SOPs by state bank about each matter as sharia compliance and products related fatwas are mandatory and it take some extra time which is major hindrance of Fin-tech adoption. 


\section{Existing Human Capital, Resources Available \& Banks Policy}

This construct discusses the availability of human and Capital resources to successfully adopt the Fin-tech in Islamic banks. Most of the respondents stress the point that Islamic banks should hire professionals in their branches to make their staff more trained and make the environment of innovation. Islamic banks, need to enhance the resources and Govt should take immediate steps to promote Fin-tech in Islamic banks. The following responses from different respondents are as follows: "Existing human capital is limited in Islamic banks. There is a need to train employees according to current trend in Islamic banks. IT issued to improve the communication system with banking employees by services, motivational lectures" (R1). "Obviously, there is lack of resources in Pakistan to flourish Islamic banking. There is a need for Islamic banks manager to hire some professionals having exposure of Islamic banking" (R4). "As a manager of window Islamic bank, I think we have very efficient and excellent staff for FinTech products and state Bank of Pakistan and regulators are working towards digitalization and innovation in domestic banking sector" (R8)

Organizational policy regarding Fin-tech is very important. Most of respondents agree that their respective organizations are supportive of any innovation. Some of the respondents are disagreed with this statement by arguing that the fin-tech requires huge investment which causes lower profitability. "Organizational support is fair enough and like other the conventional banks Islamic banking also invest in resource availability and organizational support but the willingness for FINTECH products is somewhat interrupted due to old staff and their lack of the interest and awareness in FINTECH and Islamic banking. They don't want centralized and digital banking facilities where the branch or contact person staff is missing for their sales targets as well" (R3). "The supportive element of banking industry is a customer. If you have a good customer then you have good PR, then you can utilize your resources to sell your products. If my bank is in profitable situation, I think there may be chance that banks management focus on innovation and Fin-tech" (R5)

\section{Fintech and Religiosity to Ensure Shariah Compliance}

This construct discusses the role of religiously to adopt fin-tech. Most of respondents' state that Islamic banks depend on Shariah boards. The board depends on highly Skilled Shariah scholars. They made Islamic banking totally riba free. As for as, fintech is concerned there should be a proper checking of any innovation in products through the sharia board to analyze whether it is under the principle of sharia or not. In this connection, if the sharia board approve such products then there is no issue regarding Fin-tech. "Of course, Shariah compliance is the mandatory for approval of any product before the introducing Fintech" (R1). "Technology changes the way organization manages their products. I think innovation through fin-tech is not a bad thing and in Islam, there is no prohibition of the use of fin-tech but it should be under the guidelines of sharia" (R3).

"SBP as a regulator of banks ensures that every new technology introduces to facilitate customers should be in according to sharia compliance. As Islamic banking is derived from Islamic roles and laws that's why it's really important to follow all these sharia principles" (R5). In conclusion, Fintech is easy to audit and comply with Shariah, the difficult thing is to establish standards of the Shariah compliance in Fintech and product development as per Shariah, like in all Multinationals Software's have substituted human accounting and manual audit practices, it's obvious to bring about digitization in Islamic Finance Industry as well. Infect, it helps a lot in service quality maintenance, customer satisfaction through feedback tabs in place at branches, online complaints cell web portal, and social media channels for the boasting sales and complaints feedback and reviews. 


\section{Importance and Use of Fintech in Presence of Crisis Like COVID 19}

This construct discusses the importance of Fin-tech in presence of COVID 19. In the developing countries, people need more credit and data advances to stay in contact during these challenging times, as well as contactless micro-finance services to replace physical transactions. Managing this load using the already stretched infrastructure of such markets is a significant challenge, but one where machine learning, big-data analytics, and artificial intelligence can make a difference. Different respondent's response to the question in the following lines: "FINTECH is the need of us especially in a crisis like COVID 19, banking and finance industry cannot run smoothly without it. Almost all conventional and Islamic banks have mobilized their online portal and channel to make banking nonstop in this pandemic like Meezan and other Islamic banks have made online funds transfer to other banks free, contact to customer policies are revised and customers are being more informed and educated via online channels and phone calls interaction from where they are routed to online channels. In crisis Fintech is inevitable for banking to run smoothly" (R2).

"By using digital channels and e-banking customer can protect himself and his family from COVID 19 and they can easily access banking services through fin-tech channels without paying extra costs" (R4). "Well! COVID 19 is the real test of Islamic bankers that how they respond to such situation but there is a great opportunity for Islamic banks to promote their digital products and aware people about fin-tech" (R8). Consequently, for that reasons, as argued "As seen all the operations are closed involving direct human contact the only option is to use the fintech products in the Covid-19 crises and the same can be applied in other areas" (R9). In conclusion, in the present situation, Fin-tech can help the society and customers at the individual level as well as to avoid going outside and arranging and managing financials by using different fin-tech and digital Applications.

\section{Promotion of Financial Inclusion through Fintech}

This construct discusses financial inclusion through Islamic Fin-tech. Literature suggested that Pakistan occupies low rank in financial inclusion when compared to regional and global standards (Baber, 2019). Most of the respondents believe that Fin-tech is a good tool to promote financial inclusion as people get maximum services through online channels. The following lines represent the point of view of different respondents. "Fintech is helping financial inclusion. Through the provision of multiple online facilities for both individual businesses, individuals find it easy to do banking and financing with online and convenient ways than traditional manual ways including $\mathrm{ADC}$ and online financing channels. Businesses are encouraged by real-time FinTech development like RTGS, e-biz + devices were transferring funds making payments is not only easy but also a complete track in their hands instead of traditional account statements requests. Trade and credit facilities have become less time taking than before due to FINTECH. Thus, it helps at all level infect NGO's Trust and other organization of public $n$ private sectors are benefited due to Fintech real-time facilities of collection payments and accounts maintenance" ( $\left.\mathrm{R}_{5}\right)$. "The introduction and focus of online banking in both the sample countries particularly in Malaysia expands the market share of Islamic banks". (R6). FinTech can promote financial literacy as well as financial inclusion (R7).

\section{Potentials for Fintech in Emerging Economies}

In Pakistan, there is a great potential of Islamic banking due to a religious point of view as its riba free. There is a repaid growth in the Islamic banking sector seen in Pakistan as the branches of Islamic banks are operating all over Pakistan. Some hurdles may restrict the operation of digital Islamic banking in remote areas in which internet facility, Infrastructure and customer awareness are important points for consideration. The role of government is very important in this respect as 
infrastructure should be improved for facilitating Islamic banks to flourish according to current demands. "In remote areas, it is a bit difficult practice but a great opportunity at the same time all we need a well-trained and patience staff to handle because of lack of awareness and education and backward banking practices it gets sometimes difficult to convince and educate them but at the same time it is an opportunity for Islamic banking to beat conventional and increase its market share" (R4). In this connection, "We are often in the emerging markets. In Pakistan especially, we have been repeatedly surprised by the speed of fintech adoption. Mobile payment is widely used in Pakistan as an everyday payment method, from big modern malls down to the small food cart on the corner" (R6). Therefore, "In traditional societies, there is a great potential and scoop of fin-tech but banks should heavily invest in customer's awareness and promotions" (R7).

\section{CONCLUSION}

The motivation behind this research is to investigate the potential impact of financial technology on Pakistan's Islamic banking. The findings of study indicate that fin-tech has a great potential impact on the Islamic banking industry in Pakistan. The technology used by the different banks to serve the customer is Blockchain, Mobile banking, Customer relationship management (CEM), Cyber security, Cloud Banking, and Fintech start-up, etc. This potential impact has both positive and negative effects. Active Islamic Banks (IBs) can take advantage of the opportunities offered by digital transformation and financial technology. IBS can introduce new business models, improve the product transparency and efficiency, and deliver more customer-oriented Islamic financial products and services. On the other side, if the IBs continue to avoid fin-tech then it's very hard to compete in the market. This study highlighted important points, including the need for Islamic financial institutions to respond to the development of financial technology. Fintech has become so dynamic but still exceptional. Although Islamic financial institutions realize that Fintech can have a potential impact on Islamic financial sector, they still display a certain negative attitude towards the growth of Fintech. To reap the full benefits of FinTech, it is necessary to create the synergy between the Islamic financial institutions and the FinTech companies. Both have their advantages and disadvantages, but through its cooperation, the weaknesses of each institution can be overcome by the strengths of other institutions. Islamic financial institutions should be very active in development of financial technology, and impact and potential damage cannot be ignored.

\section{REFERENCES}

Aisyah, M. (2018). Islamic Bank Service Quality and Its Impact on Indonesian Customers' Satisfaction and Loyalty. 10, 367-388. doi:10.15408/aiq. v10i2.7135.

Arvian Firmansyah, E., \& Anwar, M. (2019). ISLAMIC FINANCIAL TECHNOLOGY (FINTECH): ITS CHALLENGES AND PROSPECT.

Baber, H. (2019). Financial inclusion and FinTech: A comparative study of countries following Islamic finance and conventional finance. Qualitative Research in Financial Markets, ahead-of-print. doi:10.1108/QRFM-12-2018-0131

Baber, H. (2020). FinTech, Crowdfunding and Customer Retention in Islamic Banks. Vision, 24(3), 260-268. doi:10.1177/0972262919869765

Biancone, \& Radwan. (2019). Social finance and financing social enterprises: an Islamic finance prospective. European Journal of Islamic Finance., 1-7.

Biancone, Secinaro, \& Kamal. (2019). Crowdfunding and Fintech: Business model sharia compliant Finance. European Journal of Islamic (12).

Bryman, A. (2008). Of methods and methodology. Qualitative Research in Organizations and Management: An International Journal, 3(2), 159-168. doi:10.1108/17465640810900568 
Butt, S., \& Khan, Z. (2019). Fintech in Pakistan: a qualitative study of bank's strategic planning for an investment in fin-tech company and its challenges. Independent Journal of

Chuen, D., \& Teo, E. (2015). Emergence of Fintech and the Lasic Principles. SSRN Electronic Journal. doi:10.2139/ssrn.2668049

DinarStandard. (2018). Islamic Fintech Report. Retrieved from https://www.dinarstandard.com/wp-content/uploads/2018/12/Islamic-Fintech-Report2018.pdf

Fereday, J., \& Muir, E. (2006). Demonstrating Rigor Using Thematic Analysis: A Hybrid Approach of Inductive and Deductive Coding and Theme Development. International Journal of Qualitative Methods, 5(1), 80-92. doi:10.1177/160940690600500107

Hasan, R., Hassan, M. K., \& Aliyu, S. (2020). Fintech and Islamic Finance: Literature Review and Research Agenda. International Journal of Islamic Economics and Finance (IJIEF), 3. doi:10.18196/ijief.2122

Huei, Cheng, Seong, Khin, \& Bin. (2018). Preliminary study on consumer attitude towards fintech products and services in Malaysia. International Journal of Engineering and Technology 7 (2). doi:10.14419/ijet.v7i2.29.13310

Jamil, N., \& Abu Seman, J. (2019). The Impact of Fintech On The Sustainability Of Islamic Accounting And Finance Education In Malaysia. 14, 74-88.

KPMG. (2019). Pulse of fintech. Retrieved from

Lacasse, Lambert, \& Khan. (2017). Blockchain TechnologyArsenal for a Shariah-Compliant Financial Ecosystem. Retrieved http://publications.uni.lu/bitstream/10993/33529/1/Research\%20P

Laldin, \& Furqani. (2019). FinTech and Islamic Finance: Theory and Practice.

Lee, \& Shin. (2018). Fintech: Ecosystem, business models, investment decisions, and challenges. Business Horizons, 61(1), 35-46.

Marszk, \& Lechman. (2018). New technologies and diffusion of innovative financial products: evidence on exchange-traded funds in selected emerging and developed economies. Journal of Macroeconomics. doi: 10.1016/j.jmacro.2018.10.001

Mehmood, B., Nisar, A., \& Rehman, H. u. (2015). TECHNOLOGY MATTERS: EVIDENCE FROM PAKISTANI BANKING SECTOR USING FLEXIBLE TRANSCENDENTAL LOGARITHMIC PRODUCTION FUNCTION. Pakistan Economic and Social Review, 53(2), 203-224. Retrieved from http://www.jstor.org/stable/26153257

Milian, Spinola, \& Carvalho. (2019). Fintechs: a literature review and research agenda. Electronic Commerce Research and Applications, 34.

Ping, X., \& Chuanwei, Z. (2013). The Theory of Internet Finance.

Reuters. (2018). State of Global Islamic Economy Report. Retrieved from https://haladinar.io/hdn/doc/report2018.pdf

Rizvi, S. K. A., Naqvi, B., \& Tanveer, F. (2018). Is Pakistan Ready to Embrace Fintech Innovation? THE LAHORE JOURNAL OF ECONOMICS, 23. doi:10.35536/lje. 2018.v23.i2.A6

Silber, W. L. (1983). The Process of Financial Innovation. American Economic Review, 73(2), 8995. $\quad$ Retrieved from https://EconPapers.repec.org/RePEc:aea:aecrev:v:73:y:1983:i:2:p:89-95

Tranglo. (2020). Why Islamic fintech is more relevant than ever amid COVID-19 and the economic crisis. Retrieved from https://tranglo.com/blog/why-islamic-fintech-is-morerelevant-than-ever-amid-covid-19-and-the-economic-crisis/

Wintermeyer, Lawrence, \& Basit. (2017). The Future of Islamic FinTech Is Bright. Retrieved from https://www.forbes.com/sites/lawrencewintermeyer/2017/12/o8/the-future-ofislamicfintech-is-bright/\#47e1b19a65fa. 